\title{
A case of fungal keratitis caused by Scopulariopsis brevicaulis: treatment with antifungal agents and penetrating keratoplasty
}

\author{
Nicola K Ragge, J C Dean Hart, D L Easty, A G Tyers
}

\begin{abstract}
A case of fungal keratitis caused by $S$ copulariopsis brevicaulis following a penetrating eye injury is described. Treatment with antifungal agents and keratoplasty resulted in a favourable outcome.
\end{abstract}

A 26-year-old scene shifter received a penetrating injury to the right eye from a rusty nail embedded in a rotting, wet, wooden plank. He immediately placed a soil covered hand up to his eye. He was admitted to hospital, where emergency suturing of a corneal perforation and extracapsular removal of an opacifying lens was performed. After improvement he was discharged on chloramphenicol $0.5 \%$ drops and prednisolone $0.5 \%$ drops, both four times a day. Two weeks later he was readmitted with a progressive keratitis of the right eye. Initial cultures were negative for bacteria, but the fungus Scopulariopsis brevicaulis was grown. Treatment with chloramphenicol $0.5 \%$ drops four times a day, prednisolone $0.5 \%$ drops once a day, and amphotericin B $0.5 \%$ drops hourly was instituted, with initial improvement. One week later a secondary uveitis developed, for which dexamethasone $0 \cdot 1 \%$ drops two-hourly and cyclopentolate $1 \%$ drops three times a day were started in addition to pre-existing topical treatment. Two days later he presented at the Bristol Eye Hospital with increasing redness of the right eye and reduced visual acuity to hand movements; the left visual acuity was $6 / 5$. A dense stromal infiltrate occupying two-thirds of the cornea and a 3-4 mm hypopyon were present in the right eye. The posterior capsule was intact. A red reflex was obtained but no fundal detail. The left eye was quiet. The patient was fit except for mild asthma, treated with salbutamol inhalers but never steroids. He was not diabetic. He had had recent episodes of 'thrush' in the groin area and 'athlete's foot', which had cleared. His white cell count and white cell function tests, especially responses to fungi, were normal. Antibodies to HIV (human immunotrophic virus) were not detected. No intraocular foreign body was seen on orbital radiography.

A corneal scrape revealed a few pus cells and later on culture yielded Scopulariopsis brevicaulis, confirming the previous report. An anterior chamber tap showed numerous pus cells but no organisms. Blood cultures were negative. The sensitivities of the organism were not available initially, but it was thought that treatment with amphotericin should be continued.

As endophthalmitis was suspected; amphotericin was instilled into the anterior chamber at the time of the tap at a dose of $1.25 \mu \mathrm{g}$ in $0.1 \mathrm{ml}$.
This was calculated as $1 / 4$ of the accepted intravitreal dose. ${ }^{1-3}$ Topical steroids were stopped and hourly amphotericin $0.5 \%$ drops and cyclopentolate $1 \%$ drops three times a day continued. In addition, intravenous amphotericin $0.25 \mathrm{mg} /$ $\mathrm{kg}$ daily was given. After an initial improvement the hypopyon then increased and the cornea became more cloudy. On microbiological advice a new antifungal drug, itraconazole (Jansen Pharmaceuticals), was added at an initial dose of $200 \mathrm{mg}$ twice a day orally for 24 hours, reducing to a maintenance dose of $100 \mathrm{mg}$ twice a day. The clinical condition deteriorated further, and an emergency keratoplasty $(8.5 \mathrm{~mm}$ donor button, with removal of an $8.0 \mathrm{~mm}$ disc of cornea, including all the involved cornea) was performed. Histological examination confirmed the mycotic keratitis with isolation of Scopulariopsis brevicaulis. Following keratoplasty dexamethasone $0 \cdot 1 \%$ drops four times a day were given and the topical amphotericin $0.5 \%$ drops were reduced to four times daily. Intravenous amphotericin was stopped and oral itraconazole continued for three days.

The graft cleared and has remained transparent, with a visual acuity of $6 / 9$ with a contact lens. Later the Mycological Reference Laboratory showed the organism was resistant to amphotericin B at $20 \mu \mathrm{g} / \mathrm{ml}$ but sensitive to itraconazole $2 \cdot 0 \mu \mathrm{g} / \mathrm{ml}$.

\section{Discussion}

Scopulariopsis brevicaulis is a saprophytic soil organism. ${ }^{4}$ It has also been isolated from Californian beaches, caves in Mexico, and sauna baths in the German Democratic Republic. ${ }^{5-7}$ It

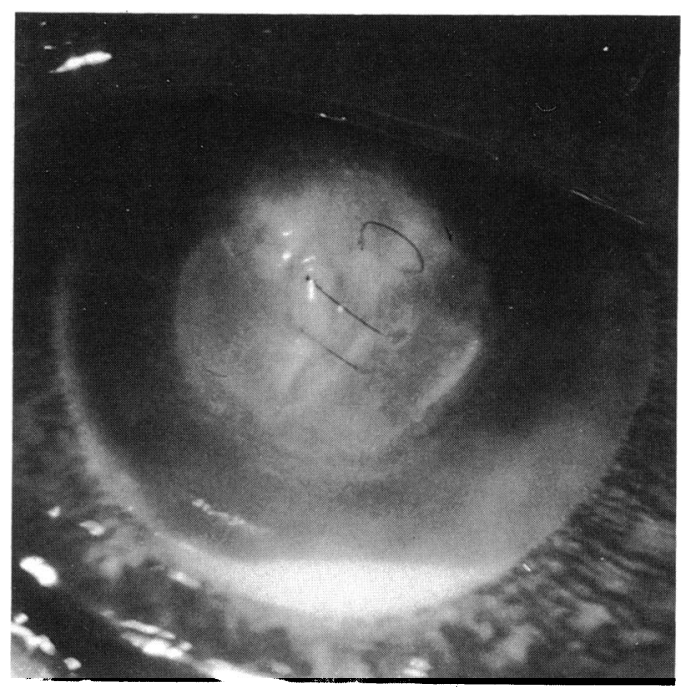

Figure 1: Fungal keratitis surrounding the sutured corneal wound in the case reported here. 
is most frequently associated with nail infections in man, ${ }^{8}$ though it has been isolated from tonsils and skin..$^{10}$ Sporadic cases of ocular infection have been recorded previously: one case of endophthalmitis following retinal detachment surgery when, despite therapy, the eye became phthisical and required enucleation;"11 one case of corneal ulcer with Scopulariopsis species in India, but with no further clinical details given; ${ }^{12}$ and two cases of keratomycosis caused by $S$. brevicaulis, again with few details of the cases or outcome. ${ }^{13}$ The infection in our case was probably acquired at the initial injury from soil contamination.

A variety of agents are effective against $S$. brevicaulis in vitro, ${ }^{14}$ though the best one for treating $S$. brevicaulis infection in man is not at present known. Although antagonism between the sterols and imidazoles is often seen in vitro, combination therapy is used successfully in vivo. ${ }^{15}$ Keratoplasty has been used successfully in the treatment of fungal keratitis in the past. ${ }^{16}$

The present case illustrates the importance of penetrating keratoplasty in removing the bulk of the fungal infection, allowing the antifungal therapy to act on any remaining infection. This should be performed immediately it is clear that medical therapy has failed to control the situation.

The authors acknowledge the help of Dr Sharon Patrick, consultant microbiologist, Odstock Hospital, Salisbury, and the Mycological Reference Laboratory, London, for initial identification of the organism, and Dr D Warnock, Department of Microbiology, the organism, and Dr D Warnock, Department of Microbiology, Bristol Royal Infirmary, for subsequent confirmation and further
advice. We are also grateful to Dr T Wallington, Department of advice. We are also grateful to Dr T Wallington, Department of function and immunological tests.

1 Forster RK. Endophthalmitis. In: Duane TD, Jaeger EA, eds Clinical ophthalmology. Philadelphia: Harper and Row, 1987; 4: Chapter 24: 11
2 Ho PC, Tolentino FI, Baker AS. Successful treatment of exogenous aspergillus endophthalmitis: a case report. $\mathrm{Br} \mathcal{F}$ Ophthalmol 1984; 68: 412-5.

3 Perraut LE Jr, Perraut LE, Bleiman B, Lyons J. Successful treatment of Candida albicans endophthalmitis with intratreatment of Candida albicans endophthalmitis with intra-

4 Morton FJ, Smith G. The genera Scopulariopsis Bainer, Microascus Zukal, and Doratomyces Corda. Mycological Mapers. Commonwealth Mycological Institute, Kew, Surrey, papers. Commonwealth Mycolo

5 Dabrowa N, Landau JW, Newcomer VD, Plunkett OA. A survey of tide washed coastal areas of southern California for fungi potentially pathogenic to man. Mycopathologia 1964; 24: $137-50$.

6 Gonzalez-Ochoa A, Dallal y Castillo E. Frecuencia de Scopulariopsis brevicaulis en muestras de suelos en cuevas y minas del pais. (Incidence of $S$. brevicaulis in soil samples from caves and mines.) Rev Inst Salubr Enferm Trop (Mex) $1960 ; 20: 247-52$

7 Gemeinhardt H, Lange H. Zur Vorkommen von Dermatophyten in Saunabadern. (The incidence of dermatophytes in sauna baths.) Dermatol Monatsschr 1974; 160: 268-77.

8 Walshe MM, English MP. Fungi in nails. Brf Dermatol 1966; 78: 198-207.

9 Heymer T. Die Pilzflora der Tonsillen. (The fungal flora of the tonsils.) Arch Klin Exp Dermatol 1958; 208: 74-80

10 Bazex A, Parant M, Ferrere J, Bazex J, Berger M. Infections à Scopulariopsis brevicaulis. Mise en évidence de son role pathogène. (Scopulariopsis brevicaulis infections. Evidence of its pathogenic role.) Ann Dermatol Venereol 1977; 104: 254 5 .

11 Nitzulescu V, Niculescu M. Panophtalmie mycotique par Scopulariopsis brevicaulis. (Mycotic panophthalmitis caused Scopulariopsis brevicaulis. (Mycotic panophthalmitis caused
by Scopulariopsis brevicaulis.) Arch Roum Pathol Exp Microby Scopulariopsis brevicd

12 Srivastava OP, Koul RL, Gupta SP. A survey of fungi from eye patients in Lucknow. Indian $\mathcal{F}$ Ophthalmol 1975; 24: 19-21.

13 Fazakas S. Zusammenfassender Bericht über die sekundaren Mykosen ben. Erkrankungen des Augenlikrandes, der Bindehaut und der Hornhaut. (Comprehensive report on the secondary mycoses in diseases of the margin of the eyelid the conjunctiva, and the cornea.) Ophthalmologica 1959, 138: 108-18.

14 Sekhon AS. Sensitivity of Scopulariopsis brevicaulis to some antimicrobial agents. Mycopathologia 1975; 57: 177-9.

15 Goodman DF, Stern WH. Oral ketoconazole and intraocular amphotericin B for treatment of postoperative Candida amphotericin B for treatment of postoperative Candida parapsilosis

16 Savir H. Anterior segment resection because of Fusarium solari keratitis and endophthalmitis. Arch Ophthalmol 1984; 102: 824-5.

17 Karimov MK, Malanova NL, Kossovskii LV. Lechebnaia Keratoplastika pri Mikozakh Rogovoi Bologchki. (Curative keratoplasty in mycosis of the cornea.) Oftalmol $\mathrm{Zh} \mathrm{1980;35}$ 484-6. 